\title{
Research on the Perfection of Disregard of Corporate Personality in Enforcement
}

\author{
Pu Wang \\ Anhui University of Finance and Economics, Bengbu 233030, Anhui, China \\ Email: 1771610039@qq.com
}

\begin{abstract}
China's current disregard of corporate personality system has several prominent problems in the mandatory enforcement procedures, such as different identification standards, difficulty in starting the enforcement procedures, and lack of supporting systems. Perfecting the application of the disregard of corporate personality system in the enforcement process can effectively alleviate the "execution difficulty" problem to a certain extent. In judicial practice, to solve the problem of difficult implementation of the main body of the company caused by the control of shareholders' abuse of the company's independent personality, on the one hand, it is necessary to improve China's company law and other related legal systems, formulate supporting standards, and incorporate the common circumstances of corporate legal personality denial into judicial interpretation. On the other hand, we should strictly grasp the scale in the execution procedure and deny the person who abuses the company's independent personality.
\end{abstract}

Keywords: enforcement, disregard of corporate personality, difficulty in execution, limited liability of shareholders

\section{Introduction}

The system of disregard of corporate personality mainly means that when the company's shareholders commit any behavior that abuses the independent personality of the company's legal person, causing actual damage to the creditor's property and interests, the corporate personality should be denied, and the shareholder who abuses power should bear the joint responsibility of the company. Since March 2014, the "Company Law" formally revised the company's registered capital from the paid-in system to the subscribed system, the counterparty of the transaction will bear more responsibilities and risks when they cooperate. After the implementation of this personality denial system, the Supreme People's Court has not yet made detailed legal explanations and specific explanations on this system, which may cause many problems in the actual implementation of the personality denial system. The lack of supporting procedures has led to the abuse of the system in practice. Even if there is no abuse, the parties may still have objections to the application of the system. In particular, the phenomenon of using the company's independent personality to evade the law and evade enforcement is particularly prominent. An important reason for "difficult execution".

\section{Reasons for disregard of corporate personality during enforcement}

\subsection{The certification standard lacks supporting facilities}

From the judicial practice in recent years, we can clearly see that the specific standards for denying the corporate personality have developed differently from the past. Compared with the chaotic social practice, the statutory law is always relatively lagging and overly vague. The article makes it embarrassing to deal with similar cases due to the different understanding of the law by the judges.

First of all, the provisions of Article 20, paragraph 3 of the "Company Law" objectively only apply to situations where the company's shareholders have abused the independent personality of the company as a legal person, causing actual damage to the legitimate interests of the creditors. However, when the actions performed by the shareholders have not caused direct or substantial damage to the legal interests of the creditors, it may not be possible to apply this system in a timely manner. This is not conducive to timely and effective protection of the legal interests of creditors, and it also increases the pressure on the subsequent identification and implementation of the disregard of corporate personality system. Secondly, the law is not specific enough for the specific application scope of the denial of corporate personality system. Therefore, imagine that if any unreasonable abuse of power is likely to be regulated by the corporate personality denial system, then the personality denial system will inevitably be abused. Moreover, it is not clear how to conduct the identification, and there are no clear relevant legal regulations on the identification standards and the degree of confusion. 
Article 20, paragraph 3 of the "Company Law" stipulates that the system of disregarding corporate personality refers to a specific legal relationship, if the company's shareholders abuse the company's independent status as a legal person and the limited liability of shareholders, evade debts, and seriously damage the interests of the company's creditors. In case of failure, they shall bear joint and several liability for the company's debts.

\subsection{Difficult to start the execution procedure}

The modern rule of law system insists on the separation of trial and enforcement. Although the power of enforcement has a certain degree of initiative, the subject of change and addition of enforced enforcement may involve a third party outside the case, so it still has a certain degree of passivity in the exercise of rights. The disregard of corporate personality system generally implements the principle of no complaint in the enforcement procedure, that is, the application of the applicant must be used to ensure the start of the procedure. In the enforcement procedure, only the creditor submits an application to the court, and the enforcement judge cannot directly apply the system of disregard of corporate personality. Zhu Ciyun also held a similar view in "The Jurisprudence Study of the Denial of Corporate Personality". It is obviously wrong to directly add the company's shareholders as the person to be executed in order to fully protect the company's creditors' claims. He believes that denying the company's independent personality is only applicable to trial procedures and cannot be applied in enforcement procedures. Otherwise, this will not only lead to the arbitrary enforcement of the law by the case-handling personnel, and the formation of a situation of "exercise on behalf of the trial". Moreover, it is easy to form legal instability, and the litigant's right of litigation cannot be protected.

\subsection{The burden of proof is defective}

According to the principle of "who advocates, who will provide evidence", the company's creditors themselves provide evidence to prove that the shareholders have indeed abused the independent personality of the company law. However, in judicial practice, creditors cannot obtain specific information about shareholders' serious damage to the company's independent personality through external corporate behavior inquiries. If this principle of proof is simply applied to cases that deny the company's legal personality, this is to a certain extent. It is not conducive to protecting creditors. Even if the creditor spends a lot of time and energy to inquire about most of the company's situation, it is impossible for the creditor to accurately find out all the company's business activities because it involves the company's trade secrets and the right to operate independently. This also makes the creditor not possible to obtain other behaviors of abuse of corporate personality in business operations in a timely manner. For the company's shareholders to abuse the company's independent personality, it is obviously unfair to simply require creditors to obtain the above-mentioned certification materials.

\subsection{Abuse in judicial practice}

On the one hand, judges often have relatively large discretionary powers, which can easily cause judges to abuse the corporate personality denial system in order to improve execution efficiency and save judicial costs when trying cases, which weakens or even shakes the foundation of the company's limited liability. The legitimate interests of both parties cannot be protected equally. For example, they are limited to hearing the words of the person applying for execution, while ignoring the right of freedom of debate and litigation rights of the person subject to execution. On the other hand, there may also be creditors who abuse their rights for their own private interests to damage the legitimate interests of the company's shareholders. The direct application of the corporate personality denial system in the enforcement procedure will limit the procedural rights of the person subject to enforcement and may seriously damage the legal rights of the executor. In addition, the direct addition of the liability of the person subject to enforcement is usually added in the form of a ruling. Once the ruling is issued by the court, the company's shareholders will not be able to remedy themselves in a timely manner.

\section{The regulations and enlightenment of disregard of corporate personality in enforcement outside the territory}

\subsection{The situation in which the United States denies the corporate personality in enforcement}

The theory of "piercing the corporate veil" was first born in the United States. The original intention was to prevent someone from improperly using the independent personality of a corporate legal person to undermine the public system and even protect crime. Since his publication in the Columbia Law Review in 1912, Wormser has gained widespread attention. However, the United States lacks the concept and legislation of the system of "piercing the corporate veil", 
and there is no uniform standard, which allows judges to have greater discretion. At the same time, since the court once activated and ruled that the company's personality was denied, it would have a huge impact on the property of the additional person. Therefore, the judge also cautiously used the system of "piercing the corporate veil".

\subsection{The situation in which Germany denies the corporate personality in enforcement}

In Germany, investors also circumvent the law for their own interests, thereby harming the interests of creditors. In order to curb this undesirable phenomenon, Germany transplanted the more mature American theory of "piercing the corporate veil" into its own country, and improved it according to its own national conditions, and then gradually developed into a more mature "straight line theory" in judicial practice. The "direct claim theory" is based on the principle of good faith, that is, when someone overuses their rights and infringes on others or even the public interest through improper means, the independent status originally conferred by the law cannot be respected.

In Germany, the scope of application of the "straight line theory" mainly includes between the company and its parent and subsidiary companies, as well as between the parent company and its shareholders. In addition, the parent company is often "directed liability" for "excessive control". If the following conditions are fully met, it can be considered that the parent company has "excessive control". First, the parent company has a long-term and absolute control; second, the parent company exercises control over its controlling subsidiaries for its own illegitimate interests; third, the parent company uses its dominant position to cause serious losses to the interests of related creditors of the subsidiaries.

Based on the analysis of German judicial practice experience for many years, it can be concluded that in the scope of application, we are committed to typed "direct claim liability", that is, there are clear case types and factual reasons for the application of "direct claim liability" to protect the applicable law stability and prevention of abuse of the corporate personality denial system.

\subsection{References and enlightenment}

American courts usually apply the system of disregard of corporate personality based on the principle of fairness and justice. In Germany, represented by the civil law system, the principles of good faith and public order and good customs are generally used to deny the corporate personality. Therefore, judges have greater discretion, and if used improperly, it will inevitably lead to chaos in social order.

In our country's company law, it is more difficult to deny the corporate personality, and there are few cases. However, since the United States and Germany have accumulated company law judgments for nearly a hundred years, our country can fully learn from the experience accumulated in these judgments in legislation and judicial practice. Based on this, in the current judicial practice of denying company legal personality, the most important thing is to take honesty and credibility as the basic principle, strictly prohibit the abuse of rights as the guiding ideology, and deal with the specific factors involved in the case of denying company legal personality. Consider it comprehensively and refine the types of denial of corporate personality in order to achieve fairness and justice in the true sense.

\section{The perfecting way to disregard the corporate personality in enforcement}

\subsection{Formulate supporting standards}

The state should be more specific, clear and operable when formulating specific provisions in the company law. To formulate operating procedures of legal norms that are compatible with the application of the company's legal personality denial system in the enforcement procedure, there must be a set of corresponding operating procedures, so as to ensure the application of the company's legal personality denial system in the enforcement procedure. It is conducive to maintaining the authority of the rule of law and can also provide protection for the use of subsequent systems.

Faced with cases of denial of corporate personality in judicial practice, when judges need to determine whether there is a denial of corporate personality in the trial, the law cannot be used as a direct criterion and legal basis for judgment. The company law cannot provide detailed explanations and regulations regarding the civil procedure of the denial of corporate personality. Only the Supreme People's Court can make clear regulations by formulating relevant judicial interpretations. It is recommended to use the principled provisions in legislation plus judicial interpretations issued by the Supreme People's Court to incorporate common situations of disregard of corporate personality into judicial interpretations to achieve uniform judicial application, ensure fairness and justice, and maximize the effectiveness of this system.

In order to achieve the standardization of the rule of denial, the standards for identifying the denial of personality should be further converged. The standard of applying the system of disregard of corporate personality in enforcement should generally be pre-procedure. When the creditor discovers that the shareholder has abused the independent 
personality of the company as a legal person and provides preliminary evidence, it may apply to the court to require the debtor company to make rectification within a prescribed period. If the debtor company cannot provide relevant materials and evidence to prove that it is impossible to have personality confusion, it must rectify the existing personality confusion within the prescribed period. Joining the pre-procedures for rectification has greatly increased the possibility that the person subject to execution will consciously perform in accordance with the law, allowing the court to have a buffer period when it denies the company's legal personality. This move is not only conducive to timely and effective protection of the legal rights of creditors, but also conducive to cautious use of the corporate personality denial system, and ease the status quo of implementation difficulties.

\subsection{Direct application of disregard of corporate personality in the execution procedure}

According to the current specific national conditions of our country, first of all, we must admit that the trial procedure is to solve all the problems that need to confirm and negate the relationship of substantive rights and obligations. But we must also further understand that trial procedures are not omnipotent, and there are many disadvantages in applying trial procedures. If such issues must be reviewed and determined by the trial organization in accordance with legal procedures, it will inevitably delay implementation and cause creditors to fail to realize their claims. Fairness and justice must be realized in an efficient way. After all, "justice late is unjust." It is necessary to directly apply the denial of personality in the execution. Improving the judicial application procedure of the system of denial of corporate personality in the enforcement will help alleviate the problem of "difficulty in execution".

In judicial practice, the applicant for enforcement usually needs to file a civil lawsuit, request the court to reconfirm the company's legal personality, and then apply for court enforcement in accordance with the effective legal documents. The litigation process is cumbersome, time-consuming, and costly. The most important thing is the person subject to execution that is very easy to transfer assets and evade debts during this process, resulting in no property for execution on the surface, thus evading execution and causing great losses to the interests of creditors. Therefore, in the judicial process of compulsory enforcement of company property cases, the laws and regulations of the disregard of legal personality system are directly used to make the companies that have direct interests, shareholders, and the actual person to be executed jointly bear the responsibility, so as to achieve the purpose of enforcement and protect the creditor's rights. Realized in a timely manner, in line with the efficiency principle required by the civil execution procedure.

\subsection{Improving the distribution system of burden of proof}

The assumption and distribution of the burden of proof should be considered from the basic aspects of fairness, justice, operability, and efficiency. However, the burden and distribution of the burden of proof cannot be allocated on the basis of "who advocates and who produces proof". After all, it is much more convenient for the company shareholders to provide the court with the financial accounts between them and the company to prove that their behavior is legal and does not abuse the company's independent personality. It is far more convenient than the creditors themselves collecting evidence to prove that the company's shareholders have done so.

Therefore, in the specific distribution of the burden of proof, the more core burden of proof should be borne by the company's shareholders (applicant for execution) that are applied for additional. Specifically, it can be divided into two steps: First, the executor applicant bears the initial burden of proof to prove that the executor applied for may indeed abuse the company's personality independence, then the remaining executor applicants do not need to provide further evidence. If accepted by the court, the remaining burden of proof shall be borne by the applicant for enforcement, that is, the rule of inversion of burden of proof shall be implemented. Then, the applicant for execution should submit the financial accounts of the company and the company's capital flow to prove that there is no abuse of the company's independent personality and does not need to bear any debts of the company. If the applicant for enforcement cannot provide the above-mentioned evidence in a timely manner or the evidence provided does not meet the principle of high probability, then the enforcement judge can rule that the applicant for enforcement is added as the enforce accordingly. This allocation of burden of proof seems unfair on the surface, but it is not. In judicial practice, the company's financial accounts, especially the company's accounting books, cannot be seen by creditors at all. The true flow of funds within the company is only known to the company's top management and shareholders. In addition, the company's account books are also the company's secrets. The court and both parties should strictly guard the company's secrets and cause no loss to the company's shareholders. In summary, it can be seen that the implementation of this partial burden of proof distribution method with the inversion of the burden of proof can efficiently resolve disputes between the parties and it is also the most fair way of proof for both parties. 


\subsection{Procedures for the protection of shareholders' rights and interests being added}

In order to protect the lawful rights and interests of the debtor, the case-handling agency shall restrictly deny the corporate personality in judicial practice, and resolutely prohibit the abuse of the creditor. To this end, an execution hearing system and a third-party objection system should be set up in the execution procedure so that the interests of both parties can be protected equally. First of all, the court should announce to the public the cases that it has not executed and will be enforced, and the third party can raise objections to the court within the statutory period after the announcement, so that the court can conduct a hearing. Fairness is achieved by placing the enforcement work of the court under the supervision of the society. Not only must the execution efficiency be guaranteed, but also the legitimate rights and interests of the additional person must be protected.

Second, it is necessary to improve the court's enforcement hearing system. The specific establishment of the court enforcement hearing system and its procedures can be referred to the court's trial system and the administrative agency's hearing system. The hearing must always insist on the separation of trial and execution, that is, the hearing team must be composed of judges within the executive bureau. In order to protect the right to debate and cross-examination of the applicant for execution, the right to apply for a hearing should be granted. The applicant for enforcement may apply for witnesses to testify at the hearing, present evidence that is beneficial to them, and have the right to participate in debates and cross-examinations at the hearing by themselves or their agents, and to explain and discuss their views on both parties or their agents.After that, the hearing team will make a reasonable ruling accordingly. The hearing team cannot make a ruling when the truth of the case is unknown, and the case ruling must be fair and just. If the hearing team believes that the execution applicant has malicious litigation after trial, criminal punishment shall also be imposed on him.

\section{Conclusion}

Based on the current situation of "difficult enforcement" in handling civil litigation in my country, this article believes that directly denying the company's independent personality in the compulsory execution procedure can not only effectively alleviate the current situation of difficulty in enforcement, but also help protect the legitimate rights and interests of interested parties. The construction and development of a fair system has far-reaching significance. At this stage, the theoretical research on company law is still immature, but the system that directly applies to the denial of corporate personality cannot be studied from a purely theoretical point of view. Instead, it should focus on specific reality and seek a suitable one with a developmental and open strategic vision. The company law system. On the one hand, this system can effectively alleviate the difficulty of implementation, and on the other hand, it can prevent the system from being abused. This requires us to seek this system on the basis of taking into account efficiency and justice. The issue is the focus of academic discussion.

\section{Acknowledgments}

This article is a scientific research fund project of Anhui University of Finance and Economics. Title: Research on the Judicial Application of the System of Disregard of Corporate Personality in Enforcement (Project Number: ACYC2019337).

\section{References}

[1] Susan Mary Watson. The corporate legal person. Journal of Corporate Law Studies. 2019; (1).

[2] Gorbaniuk Oleg.Measuring corporate personality: A critical review and new insights. Journal of Brand Management. 2017; (10).

[3] Watson Susan Mary. The corporate legal person. Journal of Corporate Law Studies. 2019; (4).

[4] Interfax. TOP NEWS:CBR to pierce bankers'corporate veil. Finance Weekly. 2020; (2).

[5] Sun Qinan. (2016) On the direct application of corporate personality denial system in civil enforcement. Master's thesis. Southwest University of Political Science and Law, Chongqing.

[6] Wang Shouchun. The application of the corporate personality denial system in the execution procedure. Academic Exchange. 2016; (12): 98-99. 